\title{
Land and Buildings Register Data Change as a Result of Construction Process
}

\section{Introduction}

The real estate cadastre, or the register of land and buildings, is one of the most important public records. It is a collection of descriptive and spatial information on land, buildings and premises. The proper functioning of the cadastre is essential for the proper functioning of the State. Based on the data contained in this register, spatial planning, real estate management, or the assessment of taxes and other payments is possible. For this reason, it is crucial that cadastral database contains updated information.

This article aims to relate the regulations of the Construction Law to the regulations of the Geodetic and Cartographic Law, in the context of updating the cadastral data, changed as a result of the conducted construction processes. The data stored in the register of land and buildings and the manner of their updating will be presented. Different types of construction processes will be discussed, along with a detailed analysis of the differences between them. The specification of the cadastral data subject to the changes during construction, reconstruction, outward extension, upward extension and adaptation, will allow for a better understanding of these processes by surveying contractors or the entities running the cadastre.

\section{Data Collected in the Real Estate Cadastre}

The register of land and buildings is defined in the Geodetic and Cartographic Law [7] as the information system

that ensures the collection, updating and making available, in the manner which is uniform for the country, information on land, buildings and premises, their owners and other entities managing or possessing this land, buildings or premises.

* AGH University of Science and Technology, Faculty of Mining Surveying and Environmental Engineering, Department of Geomatics, Krakow, Poland 
This definition, although criticized due to some substantive inconsistencies and those in the terminology [1], precisely defines the objects entered into the register of land and buildings: land (parcels), buildings and premises.

The basic and the most important object of the real estate cadastre is a record parcel. The Regulation of the Minister of Regional Development and Construction on the register of land and buildings [4] defines a parcel as follows: "A record parcel is a continuous area of land located within the boundaries of one cadastral unit, legally uniform, separated by means of boundary lines". The register collects information on the location of parcels, their boundaries, surface area, types of land use and their quality classes, denotations of land and mortgage registers and other collections of documents [7]. A record data for a parcel specified in [4] have been illustrated in Table 1.

The real estate cadastre also collects information related to buildings which are the objects associated with record parcels. A building is a roofed structure with built-in installations and technical equipment, used for permanent needs, suitable for human habitation, animals or protection of objects [6]. Over the years, the number of cadastral data describing the building has changed significantly. In the original version of the Regulation on the register of land and buildings [4], there were fourteen identified cadastral data for buildings. Since the amendment to the Regulation, which entered into force on 11 January 2016, the number of the cadastral data for buildings has increased to 27 . A full list of the cadastral data for buildings is presented in Table 2 .

An independent residential unit and premises intended for other purposes are identified in the real estate cadastre as objects associated with the record parcel and the building [7]. An independent residential unit, within the meaning of the Act on the ownership of premises [11], is a chamber or several chambers, separated by permanent walls within a building, intended for human residence which, together with auxiliary spaces, serve to fulfill housing needs. Detailed cadastral data on the premises are illustrated in Table 3.

\section{Changes in the Cadastral Database}

The register of land and buildings should contain updated information. The updating of the land register survey involves the introduction of documented changes in the cadastral database to replace data inconsistent with factual and legal status or applicable technical standards, with data consistent with factual and legal status or the applicable technical standards. The updating procedure may also aim at entering new cadastral data and eliminating incorrect data [4].

According to [7], the initiation of the proceedings aimed at updating the data contained in the cadastre can be carried out in two ways: 
- ex officio, if the changes result from the provisions of law, documents submitted by the courts, notaries or public administrative authorities, based on the resource materials or as a result of the detection of false information;

- upon request, if the request is submitted by the real property owner or the entities who are in possession of this land subject to autonomous possession.

The Geodetic and Cartographic Law [7], provides two formal ways to update the information contained in the real estate cadastre:

- by material and technical proceedings, on the basis of:

- provisions of law,

- entries in land and mortgage registers,

- final court decisions,

- final administrative decisions,

- notarial deeds,

- acts of the certification of succession and European certificates of succession,

- building construction applications, notices of the completion of construction of a building, and notifications of the demolition of a building, contained in [12],

- entries in other public registers,

- application of the interested party and surveying documentation specified in this application accepted into the National Cartographic Documentation Center, if the requested change concerns the information collected in the real estate cadastre on the properties which are in exclusive possession of the applicant or applicants,

- by way of administrative decision - in other cases.

As it is noted by Wolanin [13], the above distinction between various types of updating the real estate cadastre occurs as a result of the legal form of entering changes into the records. Both of the aforementioned forms of introducing changes adequately to the existing basis for this introduction - can be used both in the update proceedings initiated ex officio or initiated upon request.

\section{Construction Processes}

The provisions of the Construction Law [12] define construction as the execution of a building structure in a specific location, as well as reconstruction, outward extension, upward extension of a building structure. For the purposes of this article, the term construction will be referred to as the execution of a new facility on the site previously undeveloped. Types of construction, such as reconstruction, outward extension and upward extension of a building structure will also be distinguished. 
Reconstruction is the construction process during which a building structure is reconstructed after considerable destruction, often of almost the whole building, and the result of such works is a new building structure, containing elements used in the previous object [17]. A more detailed and extensive definition of reconstruction was contained in the Act on special rules for reconstruction, renovation and demolition of building structures destroyed or damaged as a result of a natural calamity [10], where this term is referred to as the reconstruction of a building structure, in whole or in part, which:

- has the size of the destroyed or damaged object - at the same location,

- has the size of the destroyed or damaged object, or with other dimensions in the same municipality in another place specified in the local zoning plan or zoning permit,

- with the permitted use of construction products other than those used in the original state.

This definition greatly expands the concept of reconstruction, allowing in particular cases both the use of other materials and conducting the construction elsewhere.

Outward extension should be understood as change in the characteristic parameters of the existing building structure, such as cubic capacity, development area, height, length, width [15]. With the increase in the development area of the building, the usable floor area increases as well. During the outward extension, a new part of the existing building structure is constructed.

During the upward extension, the height of the building increases, as well as the number of floors in many cases. Both outward and upward extensions increase the usable floor area of the structure and its cubic capacity. The main difference between these processes is associated with the change in the development area: the upward extension does not increase the development area of the structure because the new part is constructed over the existing facility. The new part of the building structure is not constructed on the ground, contrary to the outward extension [14].

The provisions of the Construction Law [12] define the concept of adaptation as completely separate. Adaptation is carrying out construction work, which results in a change in the functional or technical parameters of a building structure, with the exception of the characteristic parameters, such as cubic capacity, development area, height, length, width or number of floors. The concept of adaptation was a subject of interpretation in numerous judicial decisions. In [18] we read:

Adaptation is a special kind of execution of construction works. They are supposed to lead to changes in functional parameters (e.g. increasing the number of rooms) or technical parameters (e.g. increasing the capacity of the installation) of the existing building structure. Technical or functional parameters include any values which are expressed in units of weight or measurement of functional elements such as roof, windows, stairs, and of technical parameters such as the weight of the structure or fire resistance which are present in a given object. 
In [19] it was completed as follows: "Adaptation is a change in the functional system of the existing building structure and a change in the manner of use of a given structure". A summary and a reference of adaptation to other types of structures were contained in [20]:

Adaptation can refer exclusively to the existing building structure and is limited only to change in its functional system. In other words, if the performed works lead to a change in at least one characteristic parameter (...), they are excluded to be qualified as adaptation category. In such a situation we may deal with the outward or upward extension of a structure (...).

It is also worth mentioning, that both the construction and adaptation of a building structure require a building permit, except in the cases set out in Articles 29-31 of the Construction Law [12].

\section{As-Built Survey}

The completion of a construction process is associated with the preparation of the as-built survey. According to [12], building structures requiring a building permit, as well as objects referred to in Article 29 section 1 clauses 1a, 2b and 19a-20b of the Construction Law, are subject to the as-built survey.

The Regulation on technical standards for performing topographic and detailed measurements, as well as the analysis and submission of these measurement results to the National Cartographic Documentation Center [5], sets out the goals of the preparation of as-built surveys, which include:

- determining the data:

- which define the position and shape of building structures in the national spatial reference system;

- necessary to introduce changes in:

- cadastral database - regarding land use and buildings,

- database of geodetic records of public utilities - regarding public utilities,

- database of topographic objects - regarding building structures;

- preparation of basic trig data, referred to in [3].

One of the primary objectives of the as-built survey is to introduce changes in the cadastral database. With reference to the cadastral parcel, these changes are mainly associated with the separation of land needed to use the building which is being surveyed. Such land requires a change of its use for residential areas or other built-up land or urban areas [2]. The land used for agricultural purposes is a special case, where there is a change of use into agricultural developed land. Publication [5] emphasizes the need to introduce changes with respect to buildings. There is no reference, however, to the updating of the cadastral data regarding the premises entered into the register of land and buildings. The legislator seems to give the surveyor a free hand in entering the changes related to premises. It should be noted, 
however, that due to the general rule of "due diligence", in the event that the surveyor identifies changes regarding independent premises during the conducted survey, they should inform the authority running the register.

Any changes in the descriptive cadastral data relating to parcels or buildings, determined during the performance of surveying works, are entered in the record of changes in the cadastral data.

According to [4], such a record should include:

- the identifier of cadastral units;

- the number of the appropriate land registration unit or item of building files;

- the number of land and mortgage register;

- denotation of the object of the cadastral database, whose registration data have changed;

- the existing cadastral data and the data that result from the performed surveying works;

- the register preparation date;

- the name and surname of the contractor and the signature of the person representing the contractor;

- the name, surname and signature of the person who prepared the document and the date of its preparation;

- the name, surname and signature of the manager of the surveying works, if appointed;

- the number of professional qualifications of the person who prepared the document, or the number of professional qualifications of the manager of surveying works.

On the basis of the record of changes in the cadastral data regarding land and the record of changes in the cadastral data of buildings which are part of the as-built survey, current data will be entered into the cadastre. Surveyors have been debating for many years over the method of updating data by the authority keeping the cadastral records. With reference to the previously presented possibilities of initiating proceedings as well as the legal forms of introducing the changes, we can distinguish two positions:

1) updating at the request of the interested record entity and the surveying documentation accepted into the national cartographic documentation center specified in this request, by substantive and technical procedure;

2) updating ex officio, on the basis of the as-built survey accepted into the national cartographic documentation center database, by an administrative decision.

The first position is usually represented by the authorities running the cadastre. It allows for "faster" introduction of changes without the need to issue an administrative decision. The second position is represented by surveying contractors and property owners, who believe that commissioning of the as-built survey is a sufficient manifestation of the will to update the data by the owner, and it does not 
require the submission of an additional application. Accepting the materials to the documentation center database is equivalent to the acquisition of the necessary information by the authority, so the update should be carried out ex officio and should be completed by an administrative decision. It seems necessary to introduce legislationconcerning this issue.

\section{Cadastral Data Subject to Change Resulting from the Conducted Construction Processes}

Due to a varied scope of construction works, reconstruction, outward extension, upward extension and adaptation affect the update of other cadastral data. The performed analysis did not include the reconstruction of the building with different dimensions and in a different location. Such a case would require the setting up of new records of the building and, in the context of these considerations, it would be identified with construction. Table 1 highlights the cadastral data of a parcel undergoing changes resulting from the performance of various construction processes.

Table 1. Data registration of the plot changed as a result of construction processes

\begin{tabular}{|c|c|c|c|c|c|c|}
\hline \multicolumn{2}{|r|}{ Cadastral data of the parcel } & \multirow[t]{2}{*}{$\begin{array}{c}\text { Con- } \\
\text { struction } \\
\end{array}$} & \multirow[t]{2}{*}{$\begin{array}{l}\text { Recon- } \\
\text { struction }\end{array}$} & \multirow[t]{2}{*}{$\begin{array}{l}\text { Outward } \\
\text { extension }\end{array}$} & \multirow[t]{2}{*}{$\begin{array}{l}\text { Upward } \\
\text { extension }\end{array}$} & \multirow[t]{2}{*}{$\begin{array}{l}\text { Adap- } \\
\text { tation } \\
\end{array}$} \\
\hline 1 & Identifier of the parcel & & & & & \\
\hline 2 & Numerical description of the boundaries & & & & & \\
\hline 3 & Surface area & & & & & \\
\hline 4 & $\begin{array}{l}\text { Surface area of the contours of land use and } \\
\text { quality classes }\end{array}$ & $x$ & & $x$ & & \\
\hline 5 & $\begin{array}{l}\text { Value of the land and the date of this value } \\
\text { being determined }\end{array}$ & & & & & \\
\hline 6 & $\begin{array}{l}\text { Number of the register unit (associated with } \\
\text { the owner) }\end{array}$ & & & & & \\
\hline 7 & $\begin{array}{l}\text { Denotation of the land and mortgage } \\
\text { register }\end{array}$ & & & & & \\
\hline 8 & $\begin{array}{l}\text { Denotation of the documents defining other } \\
\text { rights to the parcel }\end{array}$ & & & & & \\
\hline 9 & $\begin{array}{l}\text { Number in the register of historical } \\
\text { monuments }\end{array}$ & & & & & \\
\hline 10 & Identifier of statistical region & & & & & \\
\hline 11 & Address of the parcel & & & & & \\
\hline 12 & $\begin{array}{l}\text { For the record parcels which are public } \\
\text { roads - numbers of these roads }\end{array}$ & & & & & \\
\hline 13 & $\begin{array}{l}\text { For the record parcels which are physio- } \\
\text { graphic objects, such as streams, water } \\
\text { reservoirs, parks, forest ranges - names of } \\
\text { these objects }\end{array}$ & & & & & \\
\hline
\end{tabular}


The construction was contained only in Table 1, because when constructing a new building, it is necessary to enter all the cadastral data related to the building and premises.

Table 2 illustrates the cadastral data concerning buildings, which are updated after reconstruction, outward extension, upward extension and adaptation. Clarification on the cadastral data presented in Table 2, numbers 8 and 11, is required. Although the legislator in [4] refers to the concept of "adaptation", it is defined much more widely than in the Construction Law. For the attribute "scope of the adaptation", the following values were provided: 1 - reconstruction within the existing cubic capacity, 2 - upward extension without changing the surface area of the building, 3 - partial demolition without changing the development area, 4-upward extension with the change of the development area, 5 - partial demolition with the change of the development area, 6 - other. A significant deviation from the interpretation contained in the Construction Law and judicial decisions can be observed here.

Table 2. Data registration of the building changed as a result of construction processes

\begin{tabular}{|c|c|c|c|c|c|}
\hline \multicolumn{2}{|r|}{ Cadastral data of the building } & \multirow{2}{*}{$\begin{array}{l}\text { Recon- } \\
\text { struction }\end{array}$} & \multirow{2}{*}{$\begin{array}{l}\text { Outward } \\
\text { extension }\end{array}$} & \multirow{2}{*}{$\begin{array}{l}\text { Upward } \\
\text { extension }\end{array}$} & \multirow{2}{*}{$\begin{array}{l}\text { Adapta- } \\
\text { tion }\end{array}$} \\
\hline 1 & Identifier of the building & & & & \\
\hline 2 & Status of the building & & & & \\
\hline 3 & Numerical description of the contour of the building & & $\mathrm{X}$ & & \\
\hline 4 & $\begin{array}{l}\text { Type of the building according to the classification } \\
\text { of fixed assets }\end{array}$ & & & & $\mathrm{X}$ \\
\hline 5 & $\begin{array}{l}\text { Class of the building according to the polish classifi- } \\
\text { cation of types of construction }\end{array}$ & & & & $\mathrm{x}$ \\
\hline 6 & $\begin{array}{l}\text { Main function of the building and other functions of } \\
\text { the building }\end{array}$ & & & & $\mathrm{X}$ \\
\hline 7 & Value of the building & & & & \\
\hline 8 & $\begin{array}{l}\text { Completion date of the construction works, and in } \\
\text { the case of adaptation of the building - also the date } \\
\text { of this adaptation }\end{array}$ & $\mathrm{X}$ & $\mathrm{X}$ & $\mathrm{X}$ & $\mathrm{X}$ \\
\hline 9 & $\begin{array}{l}\text { Degree of certainty of determining the dates referred } \\
\text { to in section } 8\end{array}$ & $\mathrm{X}$ & $\mathrm{X}$ & $\mathrm{X}$ & $\mathrm{X}$ \\
\hline 10 & $\begin{array}{l}\text { Information on the material, which was used to } \\
\text { build exterior walls of the building }\end{array}$ & & & & \\
\hline 11 & $\begin{array}{l}\text { Information on the scope of the adaptation works in } \\
\text { the building }\end{array}$ & $\mathrm{X}$ & $\mathrm{X}$ & $\mathrm{X}$ & $\mathrm{X}$ \\
\hline
\end{tabular}




\begin{tabular}{|c|c|c|c|c|c|}
\hline 12 & $\begin{array}{l}\text { Number of floors in the building which are above } \\
\text { the ground and underground }\end{array}$ & & & $x$ & \\
\hline 13 & Development area of the building & & $x$ & & \\
\hline 14 & $\begin{array}{l}\text { Usable floor area of the building established based } \\
\text { on: measurements or the information contained } \\
\text { in the building project }\end{array}$ & & $\mathrm{X}$ & $x$ & \\
\hline \multirow{4}{*}{15} & \multicolumn{5}{|l|}{ Total usable floor area: } \\
\hline & Premises which are separate real properties & & $x$ & $x$ & \\
\hline & Premises which were not separated & & $x$ & $x$ & \\
\hline & Auxiliary space belonging to the premises & & $\mathrm{X}$ & $x$ & \\
\hline 16 & Number of independent units entered in the records & & $\mathrm{X}$ & $x$ & $x$ \\
\hline 17 & Number in the register of historical monuments & & & & \\
\hline 18 & Address of the building & & & & \\
\hline 19 & $\begin{array}{l}\text { Identifiers of the record parcels on which the build- } \\
\text { ing is situated }\end{array}$ & & & & \\
\hline 20 & $\begin{array}{l}\text { Information whether the building obtained occupan- } \\
\text { cy permit in whole or in part }\end{array}$ & $\mathrm{X}$ & $x$ & $x$ & $\mathrm{X}$ \\
\hline 21 & $\begin{array}{l}\text { Identification of the part of the building which } \\
\text { obtained occupancy permit }\end{array}$ & $\mathrm{X}$ & $x$ & $x$ & $\mathrm{x}$ \\
\hline 22 & $\begin{array}{l}\text { Date when the building obtained occupancy permit } \\
\text { for the whole or for a part }\end{array}$ & $\mathrm{X}$ & $\mathrm{X}$ & $x$ & $x$ \\
\hline 23 & $\begin{array}{l}\text { Number of dwelling units consistent with the con- } \\
\text { struction documentation in a residential building }\end{array}$ & & $x$ & $x$ & $\mathrm{x}$ \\
\hline 24 & Total number of chambers in a residential building & & $x$ & $x$ & $x$ \\
\hline 25 & $\begin{array}{l}\text { Date of the demolition: } \\
\text { a) of the whole building } \\
\text { b) of a part of the building }\end{array}$ & & & & \\
\hline 26 & $\begin{array}{l}\text { Cause of the demolition of the whole building, } \\
\text { of a part of the building }\end{array}$ & & & & \\
\hline $\mid 27$ & $\begin{array}{l}\text { Information on fitting the building with internal } \\
\text { technical infrastructure adapted to high-speed } \\
\text { connections }\end{array}$ & $\mathrm{x}$ & $x$ & $x$ & $X$ \\
\hline
\end{tabular}

Source: own study based on [4] 
Table 3 presents the cadastral data of the premises which need to be updated due to the implemented construction processes.

Table 3. Data registration of the premises changed as a result of construction processes

\begin{tabular}{|c|c|c|c|c|c|}
\hline \multicolumn{2}{|r|}{ Cadastral data of the premises } & \multirow{2}{*}{$\begin{array}{l}\text { Recon- } \\
\text { struction }\end{array}$} & \multirow{2}{*}{$\begin{array}{l}\text { Outward } \\
\text { extension }\end{array}$} & \multirow{2}{*}{$\begin{array}{l}\text { Upward } \\
\text { extension }\end{array}$} & \multirow{2}{*}{$\begin{array}{l}\text { Adapta- } \\
\text { tion }\end{array}$} \\
\hline 1 & Identifier of the premises & & & & \\
\hline 2 & Serial number of the premises in the building & & & & \\
\hline 3 & Type of premises & & & & $\mathrm{x}$ \\
\hline 4 & Number of chambers in the premises & & $\mathrm{x}$ & $\mathrm{x}$ & $x$ \\
\hline 5 & Number and type of auxiliary space & & $x$ & $x$ & $x$ \\
\hline 6 & Number of storeys & & & & \\
\hline 7 & Usable floor area & & $\mathrm{x}$ & $\mathrm{X}$ & \\
\hline 8 & Surface area of auxiliary space & & $\mathrm{X}$ & $X$ & \\
\hline 9 & Address of the premises & & & & \\
\hline \multirow{3}{*}{10} & \multicolumn{5}{|l|}{ Data relating to the auxiliary space: } \\
\hline & Type of space and its usable floor area & & $\mathrm{X}$ & $\mathrm{X}$ & $\mathrm{X}$ \\
\hline & A building where the auxiliary space is located & & & & \\
\hline 11 & Land and mortgage register reference number & & & & \\
\hline 12 & $\begin{array}{l}\text { Value of the premises, if determined, and the date } \\
\text { when this value was determined }\end{array}$ & & & & \\
\hline
\end{tabular}

Source: own study based on [4]

\section{Conclusions}

- One of the primary objectives of the cadastre is to collect and make available the updated information on land, buildings and premises. Construction processes such as construction, reconstruction, outward extension, upward extension and adaptation change the cadastral data regarding parcels, buildings and premises.

- Updating the cadastral data which was changed as a result of construction processes, is performed based on the record of changes in the cadastral data, which is part of the as-built survey. 
- Due to the lack of precision in the legislature, updating the cadastral data can be initiated at the request of the party in the form of substantive law proceedings or in the course of proceedings initiated ex officio, finished with the adoption of an administrative decision. There is no consistency in defining the construction processes between the regulation on the register of land and buildings [4] and the Construction Law [12].

- Only the construction and outward extension affect the change in the cadastral data of the plot. The change applies to the surface area of the contours of land use and quality classes, and it is associated with the separation of the land necessary for the use of the building.

- The character of the individual construction processes is reflected in the changes in the cadastral data relating to the building. Some of the cadastral changes result directly from the definition of the process, e.g. a change in the numerical description of the contour of the building and an increase in the development area in the case of outward extension, or a change in the number of storeys in the case of upward extension. Adaptation may change the type or class of the building, but it will not change the development area or floor usable space of the building. The identification of the cadastral data which are changed in a given construction process allows for the proper identification of this construction type. When it is known, it is possible to specify the cadastral data to be included in the list of changes. The legislation does not devote too much attention to changes in the cadastral data concerning premises. It should be mentioned, that both the outward extension, upward extension and adaptation may result in new premises, or changes in the cadastral data of the already existing premises.

\section{References}

[1] Hanus P., Hycner R., Kwartnik A.: Analiza terminologiczna wybranych problemów katastru i zagadnień pokrewnych. Cz. 1, Działka, granica, nieruchomość. Geodeta: Magazyn Geoinformacyjny, nr 10, 2013, pp. 15-22.

[2] Hycner R., Hanus P.: Wykonawstwo geodezyjne. Wydawnictwo Gall, Katowice 2007.

[3] Rozporzadzenie Ministra Gospodarki Przestrzennej i Budownictwa z dnia 21 lutego 1995 r. w sprawie rodzaju i zakresu opracowań geodezyjno-kartograficznych oraz czynności geodezyjnych obowiazujacych w budownictwie. Dz.U. 1995, nr 25, poz. 133 [Journal of Laws 1995, no. 25, item 133].

[4] Rozporzadzenie Ministra Rozwoju Regionalnego i Budownictwa z dnia 29 marca 2001 r. w sprawie ewwidencji gruntów i budynków. Dz.U. 2015, poz. 542 - tekst jednolity z późniejszymi zmianami [Journal of Laws 2015, item 542 - consolidated text with amendments]. 
[5] Rozporzadzenie Ministra Spraw Wewnętrznych i Administracji z dnia 9 listopada $2011 r$. w sprawie standardów technicznych wykonywania geodezyjnych pomiarów sytuacyjnych $i$ wysokościowych oraz opracowywania i przekazywania wyników tych pomiarów do państwowego zasobu geodezyjnego i kartograficznego. Dz.U. 2011, nr 263, poz. 1572 [Journal of Laws 2011, no. 263, item 1572].

[6] Rozporządzenie Rady Ministrów z dnia 30 grudnia 1999 r. w sprawie Polskiej Klasyfikacji Obiektów Budowlanych (PKOB). Dz.U. 1999, nr 112, poz. 1316 z późniejszymi zmianami [Journal of Laws 1999, no. 112, item 1316 with amendments].

[7] Ustawa z dnia 17 maja 1989 r. - Prawo geodezyjne i kartograficzne. Dz.U. 2015, poz. 520 - tekst jednolity z późniejszymi zmianami [Journal of Laws 2015, item 520 - consolidated text with amendments].

[8] Ustawa z dnia 21 sierpnia 1997 r. o gospodarce nieruchomościami. Dz.U. 2015, nr 0, poz. 1774 - tekst jednolity z późniejszymi zmianami [Journal of Laws 2015, no. 0, item 1774 - consolidated text with amendments].

[9] Ustawa z dnia 27 marca 2003 r. o planowaniu i zagospodarowaniu przestrzennym. Dz.U. 2015, nr 0, poz. 199 - tekst jednolity z późniejszymi zmianami [Journal of Laws 2015, no. 0, item 199 - consolidated text with amendments].

[10] Ustawa z dnia 11 sierpnia 2001 r. o szczególnych zasadach odbudowy, remontów i rozbiórek obiektów budowlanych zniszczonych lub uszkodzonych w wyniku działania żywiołu. Dz.U. 2001, nr 84, poz. 906 z późniejszymi zmianami [Journal of Laws 2001, no. 84, item 906 with amendments].

[11] Ustawa z dnia 24 czerwca 1994 r. o własności lokali. Dz.U. 2015, nr 0, poz. 1892 tekst jednolity [Journal of Laws 2015, no. 0, item 1892 - consolidated text].

[12] Ustawa z dnia 7 lipca 1994 r. - Prawo budowlane. Dz.U. 2016, nr 0, poz. 290 tekst jednolity [Journal of Laws 2016, no. 0, item 2909 - consolidated text].

[13] Wolanin M.: Wybrane zagadnienia materialnoprawne i prawnoprocesowe aktualizacji ewidencji gruntów ibudynków, cz. III - rodzaje aktualizacji danych ewidencji gruntów. Nieruchomości, nr 6/2015, [on-line:] www.legalis.pl. [access: 15.03.2016].

[14] Wyrok Wojewódzkiego Sądu Administracyjnego siedziba w Kielcach z dnia 8 maja 2014 r. II SA/Ke 199/14.

[15] Wyrok Wojewódzkiego Sądu Administracyjnego siedziba w Krakowie z dnia 12 października 2011 r. II SA/Kr 1042/11.

[16] Wyrok Wojewódzkiego Sadu Administracyjnego siedziba w Poznaniu z dnia 22 sierpnia 2012 r. II SA/Po 528/12.

[17] Wyrok Naczelnego Sądu Administracyjnego w Białymstoku z dnia 29 marca 2001 r. $S A / B k$ 852/00.

[18] Wyrok Naczelnego Sadu Administracyjnego z dnia 25 stycznia 2013 r. II OSK 627/12.

[19] Wyrok Wojewódzkiego Sąu Administracyjnego w Łodzi z dnia 8 listopada 2011 r. II SA/Ed 1069/11.

[20] Wyrok Wojewódzkiego Sądu Administracyjnego w Lublinie z dnia 17 czerwca 2011 r. II SA/Lu 101/11. 